Article

\title{
Living on the Global Peripheries of Law: Disability Human Rights Law in Principle and in Practice in the Global South
}

\author{
Vera Chouinard (10) \\ School of Geography and Earth Sciences, McMaster University, Hamilton, ON L8S 4K1, Canada; \\ chouinar@mcmaster.ca
}

Received: 13 December 2017; Accepted: 13 February 2018; Published: 20 February 2018

\begin{abstract}
This article develops the notion that poorer nations of the Global South are particularly disadvantaged in terms of realizing disabled people's human rights in practice. This is because they are situated in what is termed the global peripheries of law. These are peripheries in which very limited human and financial resources are available to practically realize disability human rights (reflecting processes such as the outmigration of trained professionals, devaluation of currency as a condition of debt repayment, and dependence on agricultural exports and imports of expensive manufactured goods, including medicine, from the Global North). Being on the global peripheries of law also reflects legacies of colonial and neo-colonial violence and oppression in an unequal global capitalist order, such as ongoing and widespread violence against women and unsafe working conditions-both of which result in death and the geographically uneven production of impairment. This uneven production of impairment also needs to be considered as an important part of understanding disability human rights law in a global context. Following a brief overview of the U.N. convention on the human rights of disabled people and the U.N. Covenant on Economic, Social and Cultural Rights to provide a global legal context and of the Inter-American Human Rights System to provide a regional legal context, the article illustrates why it is so difficult to realize disabled people's human rights in practice in the Global South, through a case study of Guyana.
\end{abstract}

Keywords: global peripheries of law; disability; human rights; production of impairment; U.N. Convention on the Rights of Disabled People; Guyana case study

We live in extraordinary times and places. These are characterized, in part, by globalization, the concentration of wealth amongst an elite few, a deeply unequal neo-liberal global capitalist order, a rise in precarious employment particularly amongst younger persons, ageing populations in developed nations and ongoing struggles to assert the human rights of persons with impairments and illnesses, who are disabled by attitudinal and social barriers to inclusion in the Global North and South. In this article, I am particularly concerned with what it is like to be on the global peripheries of law in the poorer nations of the Global South and this is illustrated through a case study of disabled people's rights and lives in Guyana.

In this article, I conceptualize global peripheries of law as places in the world where it is particularly difficult to realize human rights in practice. Historically, these peripheries are the legacies of imperialism, and colonial and neo-colonial oppression. As such, they also reflect the deeply unequal and unjust neo-liberal capitalist global order in which we live today. I argue that this helps us to make sense of why some countries are particularly disadvantaged in terms of their capacity to improve disabled people's lives through disability human rights law. This conceptualization also builds on my earlier work on legal peripheries in disabled people's human rights in Canada (Chouinard 2001) and the notion that living the law in principle and in practice are often fundamentally at odds when we are located at the peripheries of law. 
I develop these arguments as follows. First, I provide a conceptualization of what it means to be situated on the global peripheries of law. Then, in order to provide a global human rights context, I consider the development of the United Nations Convention on the Rights of Persons with Disabilities and the U.N. Covenant on Economic, Social and Cultural Rights and some of the human rights they enshrine and aspire to. Next, I provide a regional human rights context for the subsequent case study of disabled people's human rights and lives in Guyana. I do this by considering the development and limitations of the Inter-American Human Rights System. This is followed by a case study of how disability human rights law is being lived, in principle and in practice, in the developing nation of Guyana.

\section{Conceptualizing Global Peripheries of Law}

What does it mean to be situated at the peripheries of law? For some legal scholars, it refers to occupying especially disadvantaged places in law and society (see for e.g., The Griffith Law Review (2015) special issue focusing on the links between disability and criminal law). I concur with this general meaning but with a geographer's caveat that those at the peripheries of law are also spatially disadvantaged in important ways. Still, there is more to experiences of being on the peripheries of law than this.

As the following quote suggests, being situated at the peripheries of law is also about encountering tensions or contradictions between how law is lived in discourse and in principle and how it is lived in practice:

... the socio-spatial production of legal peripheries or places in which law as discursively represented and law as lived are fundamentally at odds. These are places of 'shadow citizenship and entitlement'-important to the cultural representation of neo-liberal democracies as inclusionary and tolerant of diversity, but lived as places of profound exclusion in which basic human rights are routinely denied. It is from such peripheral, disempowered locations that disabled Canadians are struggling to claim their places in society and space. (Chouinard 2001, p. 186)

Countries of the Global South are particularly disadvantaged in this regard as a result of centuries of colonial oppression and exploitation and their disempowered positions in the current neo-liberal global capitalist order. This means that they have especially limited human and financial resources to draw upon in realizing legal rights in practice. This is reflected in processes such as the outmigration of trained professionals, including lawyers, to the Global North, historically high national debt loads and devalued currency that makes it difficult or impossible to purchase commodities such as medicine or mobility and other aids for persons with illnesses or impairments, from countries of the Global North despite depending upon these countries for such goods. As the feminist philosopher and bioethicist Jaggar (2002) explains, countries of the Global North and elites in those countries (as well as elites in the South) continue to benefit from a post-colonial neo-liberal capitalist order in which developing nations' labour power is exploited, natural and agricultural resources are exported, and in which countries are forced to buy manufactured goods (such as medicine, fertilizer and agricultural machinery) from the Global North. Such imbalances in power fuel widespread poverty and poor health, particularly amongst more vulnerable groups such as women (Jaggar 2002).

Being on the global peripheries of law is also about experiencing especially severe disjunctures between what people aspire to achieve through law and what is actually achieved in practice. I discuss and illustrate this in the case study analysis of Guyana presented later in this paper-drawing on interviews I conducted with disability activists in the country.

Existing on the global peripheries of law also involves being in especially marginal places of 'shadow citizenship'. These are places in which the state and legal system may appear to recognize and assert the human rights of vulnerable citizens such as disabled people and in doing so help to create the illusion of an inclusive society. At the same time, however, shadow citizens lack the means 
(e.g., financial, insufficient access to legal expertise and to mobility and other aids) to claim those rights in practice.

This is not to deny that there are important legacies of colonial exploitation and oppression, and life on the global peripheries of law in countries of the Global North. This is the case with respect to indigenous people and especially women and girls in countries such as Canada, for instance, who have had to struggle for legal recognition of traditional rights to land, self-governance, for Indian status, and also for freedom from oppressive practices such as forced education in church-run residential schools aimed at 'killing the Indian in the child' and assimilation, and the disappearances and murders of indigenous women (for further discussion, see for example: Bell and Anderson 2017; Hanson 2008). Violence against indigenous women is higher than that experienced by other women in Canada (Kubik et al. 2009) and has prompted a National Inquiry into Missing and Murdered Indigenous Women and Girls that commenced in 2016. Aboriginal people in countries of the Global South, such as the Amerindian people of Guyana, are arguably in even more disempowered and disabling locations on the global peripheries of law-struggling to deal with human rights abuses arising through human trafficking, very limited access to health care and education in their relatively isolated hinterland communities, contamination of water supplies (through mining of bauxite and gold), and insufficient access to resources such as culturally appropriate teaching materials that would aid in the preservation of communities' cultural heritages. Here the gap between the human rights that Amerindian people aspire to (such as equality of opportunity and the preservation of culture) and what can be delivered in practice is especially severe (Cultural Survival 2015). As I argue later in this article this is also true with respect to non-indigenous disabled persons' rights in Guyana.

There is no doubt that disabled people also remain on the margins or peripheries of law in countries such as Canada. Indeed, the Canadian Human Rights Commission (CHRC), in its 2016 report to the Parliament of Canada, noted that $60 \%$ of all human rights complaints it receives concern discrimination on the basis of disability (and many of these are related to employment) (Canadian Human Rights Commission 2016). But these are arguably not global peripheries of law in the sense of directly arising from colonial exploitation and oppression except for disabled aboriginal people who experience poorer health and greater impairment than many non-aboriginal Canadians. However, this situation is especially dire and difficult to address in countries situated on the global peripheries of law, such as Guyana, owing to very limited financial and human resources.

One advantage of conceptualizing disabled people's human rights in terms of global peripheries of law is that this helps to frame the realization and denial of those rights as matters of global injustice. This in turn encourages recognition that impairment and disability issues are intrinsically linked to people's places in a profoundly unequal global capitalist order and lends a political urgency to addressing these issues in this wider context.

\section{Getting Global and Regional: The U.N. Convention on the Rights of Persons with Disabilities and the Inter-American System of Human Rights}

The United Nations Convention on the Rights of Persons with Disabilities (CRPD), after five years of consultation between U.N. officials and states in the Global North and South and disabled persons' organizations, was adopted in December 2006. Following initial ratification by a record number of states (81) as well as the European Union, the convention came into force in May 2008 (Harpur 2012; Kayess and French 2008). The international convention was the first to explicitly address disabled people's human rights although some rights were interpreted prior to this in relation to general human rights conventions. In addition, the U.N. Convention on the Rights of the Child (which came into force in September 1990) mentioned disabled children once. In this context, the CRPD is frequently seen as a milestone in international disability human rights law and in global disability activism. There is also an Optional Protocol to the Convention that established a U.N. Committee on the Rights of Persons with Disabilities. The Committee is responsible for assessing individual and group complaints of violations of the rights of persons with disabilities in states that are party to the Convention and recommending 
courses of action to remedy them. States are also obliged to regularly report on the implementation of disabled persons' human rights to enable the Committee to monitor implementation of the Convention over time and space (Office of the High Commissioner on Human Rights 2018a). All but one of the 18 experts serving on the committee are disabled persons.

Scholars and activists, however, do not always agree on the significance and promise of the CRPD. Harpur (2012) argues that it has facilitated a paradigm shift in disability human rights law whereby there is, as in the social model of disability, recognition that people with impairments are disabled by environmental and social barriers. However, and unlike early radical social models of disability pioneered in the U.K., there is also recognition of the need to address the experiences and ramifications of impairment in disabled people's lives (such as the need for government support for rehabilitation and other services and housing that accommodates living needs). He also points out that the CRPD has helped to reinforce the importance of involving disability organizations in the development and implementation of the Convention. Degener (2016) argues that with the CRPD we have moved from a social model of disability to a human rights approach. She sees a number of advantages to this, including recognition of disabled people's inalienable right to dignity, an understanding that human rights are to be respected despite differences in mental and bodily status, and scope to think about the affirmation and denial of rights in terms of the intersectionality of identities. Megret (2008) contends that the Convention contributes not just to the recognition of universal human rights as applying to persons with disabilities but also recognizes rights, such as the right to full and equal participation in society, that reflect the specific circumstances of disabled people. Others, such as Kayess and French (2008, p. 34), are more guarded and critical in their views of the CRPD and its potential. In the conclusion to their article they argue:

If there is truly to be a shift to a coherent new disability rights paradigm in international law, it will be important that CRPD interpretation and implementation efforts penetrate beyond populist social model ideas to a more sophisticated understanding of impairment and disability in its social context. Additionally, it must be recognised that despite the CRPD's extensive exposition of disability rights, some crucial areas, including bioethics and compulsory treatment, are barely grazed by the CRPD text. The CRPD is therefore a crucial buttress and facilitator of a disability rights agenda, but it is not a proxy for that agenda. Some disability rights issues still remain untouched or undeveloped in international human rights law. Consequently, it will be important that disability human rights activists neither undervalue, nor overestimate, the role and scope of the CRPD and its potential contribution to securing the human rights of persons with disability into the future.

Others share such concerns. Freeman et al. (2015) argue that the U.N. committee attempting to oversee implementation of the CRPD, in its statement on article 12, went too far in asserting that all individuals at all times have the capacity to make decisions regarding matters such as treatment that would further other human rights goals such as receiving the best health care possible. They note that at least some disability organizations in countries such as South Africa and India have overwhelmingly supported the notion that people with mental and physical disabilities are sometimes unable to make informed decisions, for example when delusional or in a coma. In response to such criticisms, the Committee on the CRPD has insisted that in extenuating circumstances, such as when a person is in mental distress and a danger to themselves or others, that supported decision-making should take the place of decisions made by others such as health care professionals (Office of the High Commissioner of Human Rights 2018b).

Nonetheless, the legal principles of the CRPD are lofty and ambitious. As the World Health Organization (2011, p. 9) puts it:

A range of international documents have highlighted that disability is a human rights issue, including the World Programme of Action Concerning Disabled People (1982), the Convention on the Rights of the Child (1989), and the Standard Rules on the Equalisation of Opportunities 
for People with Disabilities (1993). More than 40 nations adopted disability discrimination legislation during the 1990s. The CRPD—-the most recent, and the most extensive recognition of the human rights of persons with disabilities—outlines the civil, cultural, political, social, and economic rights of persons with disabilities. Its purpose is to "promote, protect, and ensure the full and equal enjoyment of all human rights and fundamental freedoms by people with disabilities and to promote respect for their inherent dignity".

But, as indicated above, there are challenges and unresolved issues in terms of further articulating, and realizing in practice, the human rights of disabled persons. Outlining all of these is beyond the scope of the present paper (but for more detailed commentary on the Convention, see (Della et al. 2017). However, to help to put disability human rights law and disabled people's lives in Guyana in a global context, I now want to turn to a critique that is long overdue-namely, the efficacy of applying a disability human rights approach developed in relatively affluent nations of the Global North, such as the U.S. and Canada, to advancing the rights and well-being of disabled people in the Global South.

The dominance of Northern discourses that frame disability issues as matters of human rights at the global scale is, as authors such as Meekosha and Soldatic (2011) point out, a key legacy of a long historical trajectory of colonial and neo-colonial oppression. This oppression included taken-for-granted practices of valuing the ideas, social practices and societal organization of Northern nations (e.g., as modern and progressive) over those of poorer nations in the Global South (e.g., as more 'primitive' or traditional). This hegemony is illustrated, for example, by the fact that many Southern nations embraced this disability human rights campaign. This was undoubtedly important in forging international solidarity amongst disability activists and building networks for future action. What it arguably did not do, or did not do enough of, is pushing the boundaries of how disability issues are understood and addressed in nations of the Global South. Disability scholars point out that disability issues in the Global South need to be understood in terms of how nations and bodies are situated in an uneven global capitalist order that still bears the marks of colonial and neo-colonial oppression. So, for example, Meekosha and Soldatic (2011) note that one of the legacies of this oppression is the often especially deep poverty in which people in the Global South live. This poverty not only causes impairment (e.g., through malnutrition) but also causes especially severe barriers to inclusion such as lack of access to transportation, education and adequate health care.

To address such issues Meekosha and Soldatic (2011) suggest the need for a deeper, richer conception of disability issues as involving an uneven politics of impairment that is as important as disabling barriers to inclusion and well-being. In a similar vein, Chouinard $(2012,2014)$ insists on considering disability to be as much about the geographically uneven production of impairment (e.g., through war, violence against women, the organ trade, poverty and especially unsafe conditions of work in poorer nations) as it is about barriers and the violation of human rights.

There are two fundamental problems here. The first is that an exclusive focus on human rights can encourage exaggerated confidence in the power of law alone to improve disabled people's lives since it fails to explicitly critique the uneven geography of access to the resources needed to realize such rights. The second problem is that, in failing to recognize the links between the uneven production of impairment and disparities in capacities to enforce rights due to global inequality, scholars and activists miss important opportunities to explicitly frame disability issues as matters of global injustice. Some may argue that the problem is not so much the hegemony of Northern conceptions of disability as matters of human rights as it is an overly narrow conception of those rights, which fails to address issues such as violence and gender. While there is some merit to this view, it arguably remains important to look beyond human rights per se to adequately contextualize disabled people's lives and struggles for social change.

The U.N. Covenant on Economic, Social and Cultural Rights was adopted in December 1966 and opened for ratification and came into force in January 1976. Its articles outline general human rights principles and goals and as such, provide a general international framework for protecting and advancing the human rights of diverse groups such as disabled and indigenous people. Among 
the general human rights it enshrines are the rights to adequate food and freedom from hunger, to not be forcibly or otherwise removed from one's home, to enjoy the right to work and to have favourable conditions of work, to ensure the equal right of women and men to enjoy the economic, social and cultural rights set out in the Covenant, and the right to adequate health care. Article 2.2 of the Covenant commits signatory states to ensuring freedom from discrimination on various bases of human difference:

The States Parties to the present Covenant undertake to guarantee that the rights enunciated in the present Covenant will be exercised without discrimination of any kind as to race, colour, sex, language, religion, political or other opinion, national or social origin, property, birth or other status. (U.N. General Assembly 1966, p. 2)

It is important to note that the concept of the progressive implementation of economic, social and cultural human rights, which arguably simplistically assumes that these rights will be realized over time as states, even poorer nations such as Guyana, gain economic resources and the government and legal infrastructure needed to enforce them, informs the Covenant. The only caveat is that states will only be expected to act 'within the means available to them'. Specifically, Article 2.1 states:

Each State Party to the present Covenant undertakes to take steps, individually and through international assistance and co-operation, especially economic and technical, to the maximum of its available resources, with a view to achieving progressively the full realization of the rights recognized in the present Covenant by all appropriate means, including particularly the adoption of legislative measures. (U.N. General Assembly 1966, p. 2)

The Inter-American System of Human Rights pre-dates the International Convention on the Rights of Persons with Disabilities by many years. It began with the creation of the Inter-American Commission on Human Rights in 1959. This was followed in 1978 by the entry into force of the American Convention on Human Rights and establishment of the Inter-American Court of Human Rights. The articles of the American Convention cover a wide range of human rights including the right to life, security of the person, freedom, protection from inhumane treatment and the progressive implementation of economic, social and cultural rights. It also sets out the roles of the Inter-American Commission on Human Rights and the Inter-American Court, the former being responsible for investigating alleged human rights violations and determining which cases proceed to the Court (Organization of American States 2018) ${ }^{1}$. A key challenge in its early years, which coincided with the Cold War and fears about the potential spread of communism in Latin and Central America and the Caribbean, was dealing with authoritarian/military regimes responsible for murdering or 'disappearing' activists who opposed their regimes. Goldman (2009) contends that if the success of the Inter-American system is measured in terms of the reparations made for this flagrant violation of human rights in countries such as Argentina and Guatemala then it can be seen as remarkably successful. It has, however, also been plagued by on-going problems. It is seriously under-funded relative to the activities it undertakes. Despite growing needs to investigate alleged human rights abuses in the region and growing caseloads, the Commission and Court receive less than $10 \%$ of OAS funding. In the 2007 fiscal year the Commission's budget was $\$ 3,845,100.00$ (U.S. dollars) and the Court's was $\$ 1,656,300.00$ (U.S.). This compares to a budget of $\$ 72,171,000.00$ (U.S.) for the European Court of Human Rights in the same fiscal year (Dulitzky 2011, p. 134).

1 The Organization of American States was founded in 1948 in part to bolster security amongst member states in the Western hemisphere and in response to perceived threats of the spread of communism. Headquartered in Washington, D.C., the OAS gradually took on other roles such as dispute resolution between member states (e.g., regarding borders, trade) and promoting better economic, political and cultural conditions in member states. Some leaders, such as Hugo Chavez of Venezuela, have denounced the OAS as a 'puppet' of the United States. Nonetheless with the entry into force of the American Convention on Human Rights and establishment of the Inter-American Court of Human Rights, both in 1978, the OAS signaled an intent to strengthen its role in monitoring and addressing human rights issues in the region (Editors 2018). 
Under-funding has forced the Commission and Court to seek additional external funding for their activities (e.g., from Europe) but still funding falls far short of demands to investigate, document, process and litigate cases. This has resulted in insufficient personnel and a growing backlog of cases (Dulitzky 2011). It has also helped to limit the capacity of the Commission to make site visits to assess the human rights situations in some of its OAS member nations (there are 35). In the case of Guyana, it was only in 2016 that the Commission visited the country for the first time on a fact-finding mission on human rights (Rivero 2016). This is despite rampant human rights abuses such as police violence, domestic violence, violence against LGBTI youth, trafficking in women and the severe impoverishment of many vulnerable groups including disabled people. It was also six years after disability activists finally, after approximately a decade of struggle, succeeded in getting the Guyana Government to pass a Disability Act aimed at protecting disabled persons' human rights.

With these points in mind, I now illustrate why a deeper and more global conception of impairment and disability is needed in the context of understanding disabled people's rights, lives and struggles in the developing nation of Guyana.

\section{From Principle to Practice? Impairment and Disabled People's Human Rights in Guyana}

Guyana is a lower middle-income country (Gjaltema et al. 2016, p. 14) located on the northeastern coast of South America. Colonized first by the Dutch and later the British, the predominately Afro-Guyanese and Indo-Guyanese population, many descendants of slaves and indentured servants who labored on sugar plantations, is considered culturally part of the Caribbean. As of 2016, Guyana had a total population of 773,303 (World Bank 2016). Due to outmigration, there are now more Guyanese living abroad than in the country.

According to U.N. estimates $7-10 \%$ of the population of developing countries are disabled. This means that approximately 73,000 people in Guyana are disabled. In 2005, the National Commission on Disability, established in 1997 as an advisory body to the Government of Guyana, released the results of a survey of 1485 disabled people (Mitchell 2005). It noted that poverty was widespread and contributed to the production of impairment as well as financial barriers to accessing services such as health care and education (Mitchell 2005). Unemployment is widespread with $40 \%$ of the unemployed disabled people surveyed reporting that they had lost their jobs as a result of becoming impaired. Another 9\% were trained and skilled but lacked opportunities to do paid work. Negative attitudes toward and treatment of disabled people were common (affecting $79 \%$ of respondents) and included people feeling ashamed of disabled family members and keeping them hidden from public view (Mitchell 2005). These problems and others persist today (e.g., Chouinard 2014).

Guyana signed the U.N. Convention on the Rights of Persons with Disabilities in 2010 and ratified the international treaty in 2014. The treaty is meant to encourage signatory nations to enact and enforce human rights laws for disabled people. It also has established an international committee to deal with complaints about violations of disabled people's human rights. Also in 2010, after many years of lobbying by disability activists and organizations, the Government of Guyana passed a Disability Act meant to protect the rights of disabled people to accessible environments, equal opportunity in education and employment, access to services such as health care and rehabilitation, and freedom from discrimination on the basis of disability. Unfortunately, however, disability organizations and other civil society groups report that the Act is not being enforced (Worth et al. 2017).

As argued above, one of the difficulties of addressing the oppression and exclusion of disabled people in terms of human rights is that this often does not take into account the geographically uneven production of impairment at the global scale. So, for example, people in Guyana experience severe and multiple forms of violence resulting in impairment or death. Police violence against civilians is endemic with the highest rate of police shootings of civilians in the world (Chouinard 2012). There is also violence in the illegal narcotics trade. Racialized violence remains an ongoing problem. Reflecting a violent colonial past and patriarchal oppression, there are also cutlass attacks (cutlasses being used to harvest sugar cane) resulting in impairment or death. Women are most often the victims and the 
perpetrators are usually men (Chouinard 2012). According to the Guyanese organization Help and Shelter (2011) as many as two out of every three women in the country are victims of domestic violence.

With the help of three female Guyanese interviewers (named in the acknowledgements to this article), from 2007-2015, 110 disabled women and men shared their life stories. At least four of those stories were about becoming impaired as a result of violence. Three different women reported being attacked with a cutlass by male partners or acquaintances. One lost her right arm in the attack, another lost both forearms and the third lost the use of one of her hands. A fourth interviewee reported losing his sight as a result of acid being thrown in his face by members of a drug cartel (Chouinard 2012). These are criminal acts producing impairment or death and are violations of basic human rights (e.g., to security of the person), and yet such acts remain very prevalent in Guyana. It is important to recognize, as well, that these acts are harrowing and traumatic and cause not only physical but also psychological impairment. A case in point is that of Cora (pseudonym) whose story is outlined below.

Cora arrived at her daughter's house one day and hearing her screams went upstairs to a bedroom. There she found her son-in-law chopping her daughter with a cutlass. She tried to intervene but was unsuccessful. Then moments later her son-in-law chopped her daughter in the head. Her daughter moaned, "Ah me dead" and dropped to the floor. Cora fled downstairs. Even though her daughter's body was lifeless Cora continued to hear her son-in-law chopping the body upstairs. In shock, she tried to flee the house but was accosted by the son-in-law who began chopping one of her hands. Bleeding profusely, she begged him to stop saying "look at all this blood-why do you want to do that?" To her surprise he stopped and she ran next door to a friend's house for help.

Cora's story illustrates just how terrifying these instances of domestic violence can be; resulting in this case, in one woman's death and in another woman's serious physical impairment.

Why, despite laws in place that in principle protect women's human rights do these kinds of attacks persist? Part of the explanation lies in the limitations of judicial and police services. A recent report by the U.S. State Department $(2015$, p. 10) on human rights in Guyana had the following to say about domestic violence:

Domestic violence and violence against women, including spousal abuse, was widespread.

The law prohibits domestic violence and allows victims to seek prompt protection, occupation, or tenancy orders from a magistrate. The police received 2170 reports of domestic violence cases, and 1131 persons were charged. Penalties for violation of protection orders include fines up to 10,000 Guyanese dollars (GYD) (\$50) and 12 months' imprisonment. Survivors frequently were unwilling to press charges due to a lack of confidence in obtaining a remedy through the courts. Some preferred to reach a pecuniary settlement out of court. There were reports of police accepting bribes from perpetrators and other reports of magistrates applying inadequate sentences after conviction.

Marta, another woman who became impaired as a result of a cutlass attack by her male partner, lost both of her forearms. Her case illustrates the personal toll that lenient sentences take on women who are victims of chopping violence. Her partner was sentenced to seven years in jail even though Marta's impairments, impoverished conditions of life (e.g., lack of electricity and piped water in the home), and only very temporary access to extremely basic prosthetic devices meant that she would be disabled for the rest of her life. She was further disabled and excluded by attitudinal barriers that blamed her for the violent attack (e.g., gossip that she was promiscuous) and associated acts of 'shunning' and she said sadly that because of this she no longer felt a part of Guyanese society. With only one niece to assist her in her home she lived in terror that her male partner would return once he was released from jail and further injure or kill her. Such fears about vulnerability to violence were further accentuated by difficult living conditions. Dependence on her niece to assist with tasks such as turning on a generator for lighting meant that Marta had to wait alone in the dark in the evenings for her niece to return before she had light in her home.

Violence also in some cases worsened impairment and, along with barriers such as poverty and negative attitudes, worked to further marginalize and exclude disabled women in public and private 
spaces of life. Sarah, a woman who was mentally ill, was unable to communicate with her interviewer and so her mother was interviewed instead. Her mother related how Sarah was subjected to violence such as name-calling and having stones thrown at her if she ventured outside the home and into the local community because people recognized her as "not right in she head". Sarah also experienced violence in the home. It was not unusual for her children to beat her when they thought she had done something wrong in places such as the kitchen. Such experiences of abuse added to the trauma associated with being mentally ill. Sarah was also not receiving the medical treatment she needed-her home was located in a village a considerable distance away from the capital city of Georgetown and her family could not afford the transportation to either the National Psychiatric Hospital in Canje, Berbice or the Georgetown Public Hospital psychiatric ward where, at the time of the interview, only two psychiatrists were available. Guyana has a chronic shortage of psychiatrists and psychiatric support workers due to a combination of outmigration and limited resources for training. A 2013 newspaper report (Alleyne 2013), summarized the situation in the country in the following way:

\begin{abstract}
It has been twenty years since the PPP/C government took office against a backdrop of increasing numbers of mentally ill persons on the streets, but still there does not appear to be a comprehensive plan to address the problem. Mental health experts spoken to by this newspaper point out that the numbers of doctors and the facilities available remain woefully inadequate, in addition to which law reforms have not been made [there is a separate mental health act that dates from 1930]. At one point there was a mass rounding up of the mentally ill so that they would not be visible on the streets during a major event, but this was not followed up by any attempt to secure treatment for them.
\end{abstract}

Not surprisingly in such circumstances, the human rights of mentally ill people are repeatedly violated in practice as they face widespread stigma and discrimination in terms of employment and economic well-being, lack of cultural acceptance, and lack of access to services such as the judiciary, education and health care. In 2016, the Ministry of Health announced that it would open a new mental health unit in Georgetown with five psychiatrists as well as support staff (Disabled People's International, Department of Public Information 2016). It remains to be seen, however, how far this will go in diminishing mental impairment and securing human rights in practice for people with mental illness in Guyana. Concerns are already being raised that the five psychiatrists with the new unit have to service approximately 100,000 patients each and that social work and other staff are also scarce. This is in a country that has the highest rate of suicide in the world (Bhagirat 2017).

People with physical impairments also reported being abused in and/or outside the home. Mark, who was partially paralyzed on his left side as a result of a stroke, talked about the verbal abuse he was subjected to if he ventured outside his home and into the local community and how it made him feel hated and excluded. Another stroke survivor, Jim, noted how he was now shunned by and isolated from family members-with at least some believing that strokes were contagious. This meant he could not look to family for the assistance he needed with activities such as cooking and cleaning. Karen, who was missing a foot at birth, recounted how, as a young child, she overheard a nurse advising her mother to have her killed. It was a deeply traumatic experience that denied even her right to exist. As a young woman, she lived with her aunt and suffered psychological and physical abuse at the hands of the aunt's daughter and nephew. She was treated as a 'defective' outsider and mocked for not having a foot. She was told she did not have the right to make decisions in the home - even about her own belongings-and was beaten when she tried to assert this right. In desperation, she turned to the police for help but, despite physical evidence of the beatings, they did not assist. Finally, she took the only escape route open to her and moved out. Such acts of hate and devaluation, isolation and neglect, and violent oppression clearly violate disabled people's human rights to inclusion, respect, safe and secure environments, and in cases such as Karen's even the right to life itself.

Extreme economic disadvantage was a fact of life for many of the people with impairments and illnesses interviewed. Of the 81 interviewees for whom employment status is known, only four were in full-time employment: Bob was mobility impaired and used a wheelchair and worked at shoe 
repair in a market stall in Georgetown, Nigel, also mobility impaired and a wheelchair user, worked in an office staff position at Guyana Power and Light, Jody was visually impaired and worked as a local radio host in Georgetown, and Trisha, who was mobility impaired and a wheelchair user, also worked in an office job. Three interviewees reported sporadic employment (e.g., selling small items, tiling, making chair backs) with two of these (both wheelchair users and visibly impaired) noting that customers paid them less than their able counterparts because they were disabled. The remainder of the interviewees struggled to survive on meager government income assistance (the equivalent of one to two U.S. dollars per day). In three cases, this was augmented by periodic small remittances from family living abroad but this source of income was unreliable.

Poverty and discrimination act as barriers to mobility and accessing spaces such as those used for disability activism and the provision of health care. Representatives of disability organizations based in Georgetown interviewed by the author noted that their membership declined quickly due to the high costs of transportation to meetings. Guyana does not have public or paratransit systems and relies on private mini-buses or taxis for persons who cannot afford private vehicles or who are unable to drive. The mini-buses are highly profit-driven and focus on having as many passengers as possible as well as quickly arriving at destinations so that more passengers can embark and pay for transit. The former is a problem because mini-bus drivers frequently refuse to stop to pick up visibly impaired people such as those using wheelchairs or walkers. This is because their aids take up space that could otherwise be filled by paying passengers. The latter emphasis on arriving and departing quickly also contributes to impairment and death as a result of accidents. The problem of being refused mini-bus transit service was sufficiently severe to prompt disability organizations to launch a 'right to ride' campaign. Unfortunately, the campaign was unsuccessful for the most part and so disabled people continue to be denied rights to the mobility they need to be able to access spaces that could help to empower and enable them in their daily lives.

Widespread poverty amongst disabled people also acts as a barrier to accessing aids such as wheelchairs and walkers and the prostheses made in the single rehabilitation centre in Georgetown. Costs to import aids such as wheelchairs are high and this means that most are provided by charitable organizations such as Food for the Poor. Even so, these aids are not available to everyone who needs one. It is also expensive to import materials for prostheses, and with patients expected to cover the costs of materials (with the government and donors covering overhead and labour costs), lack of income acts as a barrier to accessing the prosthetic devices that people, such as Marta, need to mitigate impairment and lead more enabling lives. The Ptolemy Reid Centre in Georgetown, a rehabilitation centre, which now houses the only prosthetic unit in the country, estimates that since this service commenced in 1994 it has assisted 2000 people with prosthetic devices (Charles and Chigbo 2017). Still, access to prosthetic aids remains a problem for people such as Marta.

Cultural attitudes and practices also contribute to the violation of the human rights of persons with disabilities in Guyana. Rights to inclusion and equal opportunity are often compromised in practice when family members feel ashamed of a disabled family member, and as a result, hide them away in the home. It is not uncommon for disabled children to be kept hidden and out of the educational system for life. In some cases, disabled children are even chained to heavy furniture such as beds so they cannot leave the house. Such forced isolation also helps to explain why facilities such as the Open Doors Centre, a national job training centre for disabled people located in Georgetown, has had difficulties recruiting students for its programs—even though these are badly needed (Kaiteur News 2017). Disability activists interviewed as part of this study also point out that such practices contribute to low turnouts at public disability events, perceptions that there are not many disabled people in Guyana and politicians who have been slow to act on disability issues. Activists believe these are some of the reasons why it took almost a decade of lobbying to pressure the government into enacting a national Disability Rights Act in Guyana.

Whatever the challenges of realizing disabled people's human rights in practice in Guyana, the ten leaders of disability organizations who were interviewed as part of this study insisted that progress 
on disability issues would only be made once a national Disability Human Rights Act was in place (as noted above this happened in 2010). This in part reflects the global hegemony of a human rights framework for understanding disability issues. But it is also a significant 'leap of faith' that the Act will be enforced through the courts and government agencies. Also civil society organizations, as noted above, report that to date this has not been the case. This is perhaps not surprising in a context in which financial and human resources to address disability issues are very scarce, reflecting processes such as dependence on the importation of expensive manufactured goods from the Global North, the devaluation of currency as a term of debt repayment, and the outmigration of trained professionals from the country. This is not to say there is no progress on disability issues. The disability movement has developed over time in the country and leaders of such organizations as Young Voices of Disabled People contend that awareness of disabled people and their rights is on the rise (Admin 2013). Still, there is, arguably, a pressing need to consider the situation in Guyana in terms of the globally uneven geographic production of impairment. Legacies of a violent and patriarchal colonial past persist in pervasive violence, particularly against women-violence that results in impairment and even death. The high cost of importing aids such as wheelchairs or materials for prostheses mean that not all who need these aids to mitigate impairment receive them. This is also exacerbated by the outmigration of trained medical professionals in search of better wages and working conditions. Transportation costs, a chronic shortage of mental health professionals, and high costs of some medications, mean that people with mental illness also do not receive the treatment they need to diminish mental impairment. Many disabled people face poverty and discrimination in terms of access to transportation compounding their limited mobility and excluding them from potentially empowering and enabling spaces of life such as disability organization meetings.

\section{Where Do We Go from Here? Towards Enabling Geographies of Impairment and Disability in the Global South}

In this article, I have argued for a richer and deeper understanding of the geographically uneven production of impairment and disabling conditions of life at the global scale, and in countries of the Global South. Such an approach recognizes the legacies of a long and violent history of colonial and neo-colonial oppression manifest, for instance, in the chopping violence against women that still occurs in Guyana and results in impairment, death, the lack or loss of employment, deepening poverty and other disabling conditions of life. Patriarchal oppression is also at work here as manifest, for example, in tendencies to blame women for the violence they experience and related practices such as 'shunning' or avoidance. This too, has disabling consequences such as socio-spatial isolation. Marta, the woman who lost both forearms to chopping was, for instance, also deeply distressed to learn through the grapevine that one of her nephews was threatening his girlfriend with the same form of violence if she did not 'stay in line'. As the Guyana case study helps to show, cultures of disability are also geographically uneven and this is important to consider when assessing why human rights enjoyed in principle are not being realized in practice. While there are some cultural commonalities between Guyana and countries of the Global North, such as activists embracing a human rights perspective on disability issues, there are also divergences as well. The latter include the especially severe stigma and shame associated with mental and physical impairment and associated practices such as keeping disabled family members hidden away in the home. We also need to be cognizant of people's and nations' places in the uneven global political-economic order, as shown in Guyana's case by widespread and deep poverty that both causes impairment and exacerbates disabling conditions of life (e.g., through lack of access to prostheses, medicine). Disabled people in Guyana are also disadvantaged by the outmigration of trained professionals such as lawyers and doctors and the strain this puts on already very limited training resources. Nor is it surprising that rampant human rights abuses persist given the country's disadvantaged place in the international human rights system, as illustrated in this article with respect to the Inter-American system. There are, of course, internal factors at work here, such as corruption and bribery. The RefWorld (2016) report on human rights in 
Guyana notes that it is not uncommon for magistrates to be bribed in exchange for imposing lighter sentences on violent offenders, or for women who are victims of violence not to report it to the police because they do not think justice will be served in court.

One advantage of thinking about disability human rights laws and issues in terms of global peripheries of law is that it also encourages us to understand that the production of impairment and disabling conditions of life are both global justice issues and need to be considered in that wider context. This approach also allows us to problematize both impairment and disability as about more than simply the violation of human rights. The Rana Plaza collapse in April 2013 in Bangladesh, for example, killed almost 1300 people and injured and impaired more than 2500 others (mostly as a result of the need for amputation of crushed limbs). This tragedy occurred because plant owners/managers valued profit over human safety and forced workers to continue to labour in a garment factory that they believed to be unsafe as a result of cracks in the walls that they had noticed the previous day (The Guardian 2015). The case drags on in the courts in Bangladesh but critics argue that too little is being done to make conditions in garment factories safer and prevent injury, impairment and death (Jazeera Media Network 2016). The case illustrates how the production of impairment in the Global South goes hand in hand with treating workers as cheap, exploitable and easily replaced. It also shows how the violation of human rights to a safe and secure workplace can have profoundly disabling consequences. Many of those injured in the collapse can no longer work due to psychological trauma as well as physical injuries-this in turn contributes to poverty and an inability to purchase necessities such as medicine, food and transportation.

Taking the uneven production of impairment and illness seriously also allows us to better appreciate the complex interconnections between violations of human rights, impairment, and disabling conditions of life across a wider range of phenomena. Women forced into the global sex trade, for example, often have documentation such as passports confiscated by traffickers and pimps to help ensure that they do not try to flee. In the country illegally, they are afraid to turn to the police for help because of the threat of deportation. Threats of violence are also sometimes made against family members back in the women's countries of origin as a way of 'keeping them in line'. The sex trafficking of women, as well as children, violates human rights to life, liberty and security of the person (UN Women 2017), but it also often results in psychological and physical impairment. It is worth noting that trafficking often occurs from poorer, less developed nations to more developed ones-this is because of disabling conditions of life such as widespread poverty that make women and children more desperate for income and jobs, and thus more vulnerable to traffickers.

Finally, if we consider the production of impairment and illness and disabling conditions of life such as poverty, global inequality and discriminatory acts that cause impairment and violate disabled people's human rights, to be matters of global injustice, then we can begin to imagine a more enabling and inclusive world. But building such a world in practice will take courage and the determination to do things differently by, for example, challenging ableist practices of evaluating job performance in terms of quantity rather than quality and failing to recognize the extra work that disabled people often do to be part of our workplaces in the first place. It will take a redistribution of wealth from the Global North to the South to sustain more enabling conditions of life (such as better working conditions, access to prostheses and other aids) in the long-term. It will also require a fairer distribution of wealth between the elite few and most people in countries of the Global South, such as Guyana, so that barriers to disabled people's inclusion and well-being, such as grinding poverty can be eliminated. Also, it will take ongoing efforts to 'think outside the box' of framing disability issues exclusively in terms of human rights as conceived of in countries of the Global North. Nations in the Global South have a critical role to play in encouraging a more expansive, encompassing view of the issues at stake in our highly unequal global capitalist order-an order which disproportionately impairs, sickens and disables people in the Global South. Scholars, political leaders and disability activists in these countries are well positioned to raise awareness about the human suffering and denial of rights that a 
globally unequal geography of impairment and disability entails. It is high time that we work toward the kinds of changes that will help to make being on the global peripheries of law a thing of the past.

Acknowledgments: I would like to thank the disabled women and men in Guyana who shared their life stories and the three Guyanese women who assisted with interviews with them: Cora Belle, Halima Khan, and Norma Adrian.

Conflicts of Interest: The author declares no conflicts of interest.

\section{References}

Admin. 2013. Advocate Calls for Implementation of Disability Act. Guyana Times International, January 4. Available online: http:/ / www.guyanatimesinternational.com/?p=22998 (accessed on 1 December 2017).

Alleyne, Oluatoyin. 2013. Mental Health Care in Guyana. Lack of psychiatrists, facilities, support. Staebroek News, July 7.

Bell, Catherine, and William B. Anderson. 2017. Indigenous Rights in Canada. Revised by Gretchen Albers. Note Entry Originally Published in 2006. Available online: http:/ / www.thecanadianencyclopedia.ca/en/article/ aboriginal-rights/ (accessed on 2 November 2017).

Bhagirat, Lakhram. 2017. Mental Health Unit making strides in care delivery. Guyana Times, June 20. Available online: https:/ / guyanatimesgy.com/mental-health-unit-making-strides-in-care-delivery/ (accessed on 7 December 2017).

Canadian Human Rights Commission. 2016. Annual Report to Parliament. Available online: http://www.chrcccdp.gc.ca/eng/content/publications (accessed on 4 June 2017).

Charles, Collin, and Samuel Chigbo. 2017. Reintegrating People with Disabilities. Kaiteur News, April 30. Available online: https:/ / www.kaieteurnewsonline.com/2017/04/30/reintegrating-people-withdisabilities / (accessed on 30 November 2017).

Chouinard, Vera. 2001. Legal Peripheries: Struggles over Disabled Canadians' Places in Law, Society and Space. The Canadian Geographer 45: 186-97. [CrossRef]

Chouinard, Vera. 2014. Precarious Lives in the Global South: On being disabled in Guyana. Antipode 46: 340-58. [CrossRef]

Chouinard, Vera. 2012. Pushing the Boundaries of Our Understanding of Disability and Violence: Voices from the Global South (Guyana). Disability and Society 27: 777-92. [CrossRef]

Cultural Survival. 2015. Convention on the Economic, Social and Cultural Rights Shadow Report Submission: Indigeneous Rights Violations in Guyana. Paper presented at the 56th Session, Geneva, Switzerland, September 21-October 9. Available online: http://tbinternet.ohchr.org/Treaties/CESCR/Shared\% 20Documents/GUY /INT_CESCR_CSS_GUY_21656_E.docx (accessed on 11 January 2018).

Degener, Thereisa. 2016. Disability in a Human Rights Context. Laws 5: 35. Available online: http:/ /www.mdpi. com/2075-471X/5/3/35 (accessed on 13 February 2018). [CrossRef]

Della, Fina, Valentina, Rachele Cera, and Giuseppe Palmisano, eds. 2017. The United Nations Convention on the Rights of Persons with Disabilities: A Commentary. Berlin: Springer.

Disabled People's International, Department of Public Information. 2016. New Mental Health Unit to Open in Georgetown. Available online: http:/ / www.dpi.com/ (accessed on 7 December 2017).

Dulitzky, Ariel. 2011. The Inter-American Human Rights System Fifty Years Later: Time for changes. Quebec Journal of International Law (Special Edition) 127: 127-64.

Editors. 2018. Organization of American States. Encyclopedia Britannica. Available online: https://www.britannica. com/topic/Organization-of-American-States (accessed on 14 February 2018).

Freeman, Melvin C., Kavitha Kolappa, Miguel Calas de Almeida, Arthur Kleinman, Niko Makhasvili, Sisifo Phakiahi, Benedetto Saraceno, and Graham Thornicroft. 2015. Reversing hard won victories in the name of human rights: a critique of the General Comment on Article 12 of the U.N. Convention on the Rights of Persons with Disabilities. Lancet Psychiatry 2: 844-50. [CrossRef]

Gjaltema, Taeke, Candice Gonzales, and Louise Ebbeson. 2016. An analysis of the status of implementation of the Convention on the Rights of Persons with Disabilities, ECLAC headquarters for the Caribbean, Studies and perspectives series. Available online: http://200.9.3.98/handle/11362/5043 (accessed on 14 February 2018).

Hanson, Stephen. 2008. The Residential School System in Canada. Available online: http:// indigenousfoundations.arts.ubc.ca/the_residential_school_system/ (accessed on 2 November 2017). 
Harpur, Paul. 2012. Embracing the new disability rights paradigm: The importance of the Convention on the Rights of Persons with Disabilities. Disability $\mathcal{E}$ Society 27: 1-14.

Help and Shelter. 2011. Domestic Violence Pamphlet. Georgetown: Help and Shelter.

Jaggar, Alison M. 2002. Vulnerable Women and Neoliberal Globalization: Debt Burdens Undermine Women's Health. Theoretical Medicine and Bioethics 23: 425-40. [CrossRef] [PubMed]

Jazeera Media Network. 2016. Rana Plaza Court Case Postponed in Bangladesh. Bangladesh News: Al Jazeera, August 14. Available online: http:/ / www.aljazeera.com/news/2016/08/rana-plaza-tragedy-bangladeshputs-18-trial-160823051641161.html (accessed on 6 December 2017).

Kaiteur News. 2017. Open Doors Centre Marks 15 Years, Strives for Inclusivity. Kaiteur News. Available online: https: / www.kaieteurnewsonline.com/2016/05/14/open-doors-centre-marks-15-years-strivesfor-inclusivity/ (accessed on 1 December 2017).

Kayess, Rosemary, and Phillip French. 2008. Out of Darkness into Light? Introducing the Convention on the Rights of Persons with Disabilities. Human Rights Law Review 8: 1-34. [CrossRef]

Kubik, Wendee, Carrie Bourassa, and Mary Hampton. 2009. Stolen Sisters, Second Class Citizens, Poor Health: The Legacy of Colonization in Canada. Humanity and Society 33: 18-34. [CrossRef]

Meekosha, Helen, and Karen Soldatic. 2011. Human Rights and the Global South: the case of disability. Third World Quarterly 32: 1383-98. [CrossRef]

Megret, Frederic. 2008. The Disabilities Convention: Human Rights of Persons with Disabilities or Disability Rights? Human Rights Quarterly 30: 494-516. [CrossRef]

Mitchell, Hannah. 2005. Raising the Profile of Disability in Guyana: An Agenda for Action. Georgetown: National Commission on Disability.

Office of the High Commissioner on Human Rights (OHCHR). 2018a. The Optional Protocol to the Convention on the Rights of Disabled Persons. Available online: http:/ / www.ohchr.org/EN/pages/home.aspx (accessed on 1 February 2018).

Office of the High Commissioner of Human Rights (OHCHR). 2018b. Convention on the Rights of Persons with Disabilities: Article 12 Equal Recognition by the Law Subsection 3 on the Right to Supported Decision-Making. Available online: www.ohchr.org (accessed on 4 February 2018).

Organization of American States. 2018. The American Convention on Human Rights (ca. 1969). Available online: www.oas.org/dil/treaties_B-32_American_ConventiononHuman_Rights.pdf (accessed on 24 January 2018).

RefWorld. 2016. Country Reports on Human Rights Practices-Guyana. Available online: http:/ /www.refworld. org/country, ,, GUY, 58ec8a2c13,0.html (accessed on 14 February 2018).

Rivero, María Isabel. 2016. IACHR Concludes Working Visit to Guyana. OAS Press Release. Available online: http:/ / www.oas.org/en/iachr/media_center/preleases/2016/148.asp (accessed on 24 January 2018).

The Guardian. 2015. Rana Plaza Collapse: dozens charged with murder. Available online: https://www. theguardian.com/world/2015/jun/01/rana-plaza-collapse-dozens-charged-with-murder-bangladesh (accessed on 4 June 2017).

U.N. General Assembly. 1966. International Covenant on Economic, Social and Cultural Rights. December. Available online: http:/ / www.ohchr.org/Documents/ProfessionalInterest/cescr.pdf (accessed on 25 January 2018).

UN Women. 2017. Sex Trafficking Is a Grave Violation of Human Rights and a Form of Violence against Women and Children, U.N. Entity to End Violence against Women and Children. Available online: http:/ / www.endvawnow.org/en/articles/538-sex-trafficking-is-a-grave-violation-of-humanrights-and-a-form-of-violence-against-women-and-children.html (accessed on 6 December 2017).

U.S. State Department. 2015. Country Reports on Human Rights Practices: Guyana. Washington: United States State Department Bureau of Democracy, Human Rights and Labour.

World Bank. 2016. 2016 population Guyana. Available online: https.2016populationGuyana (accessed on 15 February 2018).

Worth, Nancy, Laurence Gagnon-Simard, and Vera Chouinard. 2017. Disabling Cities. In Urbanization in Global Context: Canadian Perspectives. Edited by Peake Linda and Alison L. Bain. Oxford: Oxford University Press, pp. 309-25.

(C) 2018 by the author. Licensee MDPI, Basel, Switzerland. This article is an open access article distributed under the terms and conditions of the Creative Commons Attribution (CC BY) license (http:/ / creativecommons.org/licenses/by/4.0/). 